\title{
Peer-to-peer learning through research: a case study in delivering a healthcare message
}

\section{Sadaf llias}

University of Manchester, UK

Jill Barber

University of Manchester, UK

\begin{abstract}
This article describes a recent learning activity involving pharmacy undergraduate students in which a final (fourth) year student trained 21 second year students to administer questionnaires about antibiotic resistance to over 700 student users of a large university building. The aim was to raise awareness of the problem of antibiotic resistance. The second year students were also trained to correct any misapprehensions held by the questionnaire participants about antibiotic resistance, and to encourage them to become 'Antibiotic Guardians'. Finally, the 22 students analysed the data to give a picture of what the other students understood about antibiotic resistance. Peer-assisted learning therefore cascaded from a single fourth year student to 21 second year students and then to over 700 students from various disciplines and year groups. The first stage of the cascade was evaluated and the 21 second year students overwhelmingly believed that their knowledge of antibiotic resistance was enhanced. A follow-up study using the same questionnaire will be used to determine whether the exercise was effective in raising awareness of antibiotic resistance among the body of students surveyed.
\end{abstract}

Keywords: peer-to-peer learning cascade; learning through research; antibiotic resistance.

\section{Introduction}

Among the most important duties of a healthcare professional is the education of the public, both patients and those who do not regard themselves as patients, in caring for 
themselves. It is important that the public understand, for example, the risks of smoking, the nutritional benefit of green vegetables and the value of exercise. In the internet age, members of the public are highly informed about their own health, but are also prey to a great deal of misinformation. The popular press and social media are rich sources of healthcare myths, some of which, such as the suggestion that triple vaccines can cause autism, can cause serious harm (Godlee et al., 2011).

Healthcare professionals have the training, but not always the time or the resources (easy access to the primary literature) to evaluate the healthcare advice that interests their patients. Students in healthcare disciplines have the skills and knowledge to address at least some of these issues and are required to practise communication on healthcare matters. Communication is core to the role of a pharmacist especially and is reflected in many of the educational standards required by the professional body (GPhC, 2011), for example, 'Standard 10.2.4h: Provide accurate written or oral information appropriate to the needs of patients, the public or other healthcare professionals'. It should therefore be possible to design a course unit in which healthcare students, specifically pharmacy students in this case, can practise communication by educating the public in an important aspect of healthcare. Practice in peer-to-peer learning is also strongly encouraged by the professional body, for example, 'Standard 10.1f: Contribute to the education and training of other members of the team, including peer review and assessment'.

In their applications to university, healthcare students usually mention a desire to improve the lives of others and often back up their claims with evidence of volunteering. We believed, therefore, that the opportunity to disseminate a healthcare message in a controlled environment at an early stage of their course would prove popular with students.

Antibiotic resistance is extremely topical (Pinder et al., 2015; Cameron, 2014). Since the commercial production of penicillin in 1942, antibiotics have played a major role in preventing and treating bacterial infection (for example, Kollef et al., 1999). Almost immediately after their widespread introduction, however, resistance to antibiotics began to emerge. Resistance is an almost inevitable result of overuse and inappropriate use of these precious drugs. Patients who demand antibiotics when they present with viral infections, such as colds and flu, are a menace. Antibiotics are becoming less effective in treating infections and this has imposed a major threat to health and to the economy. In Europe approximately 24,000 deaths occur annually as a result of antibiotic resistant 
bacteria (a number set to rise dramatically) and the cost burden of multi-drug resistance was conservatively estimated to be $€ 1.5$ billion in 2007 (European Centre for Disease Control, 2009; Gandra et al., 2014). Antibiotic resistance was therefore chosen as an excellent topic for a peer-to-peer learning cascade.

This article describes an exercise in peer-assisted learning in which knowledge about antibiotic resistance was cascaded from a single final year pharmacy student to 21 second year students to over 700 student users of a large university building. Additionally, data about their understanding of antibiotic resistance was collected from the 705 participants, providing the 22 pharmacy students with an opportunity to learn through research.

The final year student was carrying out a short project comprising $60 \%$ of a 30 -credit unit 'Critical Analysis and Communication' (Demonacos et al., 2014; Barber, 2015). This is a research unit with a strong practice focus, designed to train students in the analysis and communication of research data and to empower them to undertake small research projects in a practice setting. Thus, $40 \%$ of the unit is didactic, focusing on analysis of scientific claims in both the scientific literature and the popular press. Research ethics are also covered, with a focus on ethical data acquisition, storage and dissemination when human subjects are involved. The 'project' material may be the design of a detailed protocol (which is not carried out) or a simple non-laboratory project (typically involving a meta-analysis or a survey).

\section{Aims}

The aims of the project were formulated as follows:

- To embed the students' understanding of antibiotic resistance by enabling them actively to promote an understanding of the issue in other people.

- To enable students to take an active (but adequately supervised) part in public health education prior to qualification as pharmacists.

- In a small way to improve public understanding of antibiotic resistance, thereby saving lives. 
Logistics dictated further desirable aims. A student with a clipboard saying 'May I ask you a few questions?' is likely to be much more confident than a student with no props asking 'May I tell you about antibiotic resistance?'. Further, the questioning approach will yield data, leading to further educational benefit, and enabling the activity to qualify for modest funding. We therefore considered an activity in which students would question other students or members of the public about their perceptions of antibiotic resistance and would then seek to fill any gaps in their understanding.

Peer-to-peer instruction (Crouch and Mazur, 2001) presented itself as a natural method of delivery. Data collection and communication of information about antibiotic resistance could, with suitable training, be carried out by second year students, whereas coordination of the project and data analysis was suitable for a final year project. Two further objectives were then incorporated into this activity, known as the Antibiotic Resistance Survey:

- To provide an opportunity for learning through research for both second and fourth year students.

- To enhance second year students' understanding of antibiotic resistance by peer instruction.

The aims of the project are summarised in Figure 1. 
Figure 1. Graphic summarising the Antibiotic Survey, showing both the cascade of peer instruction and the collection of research data.

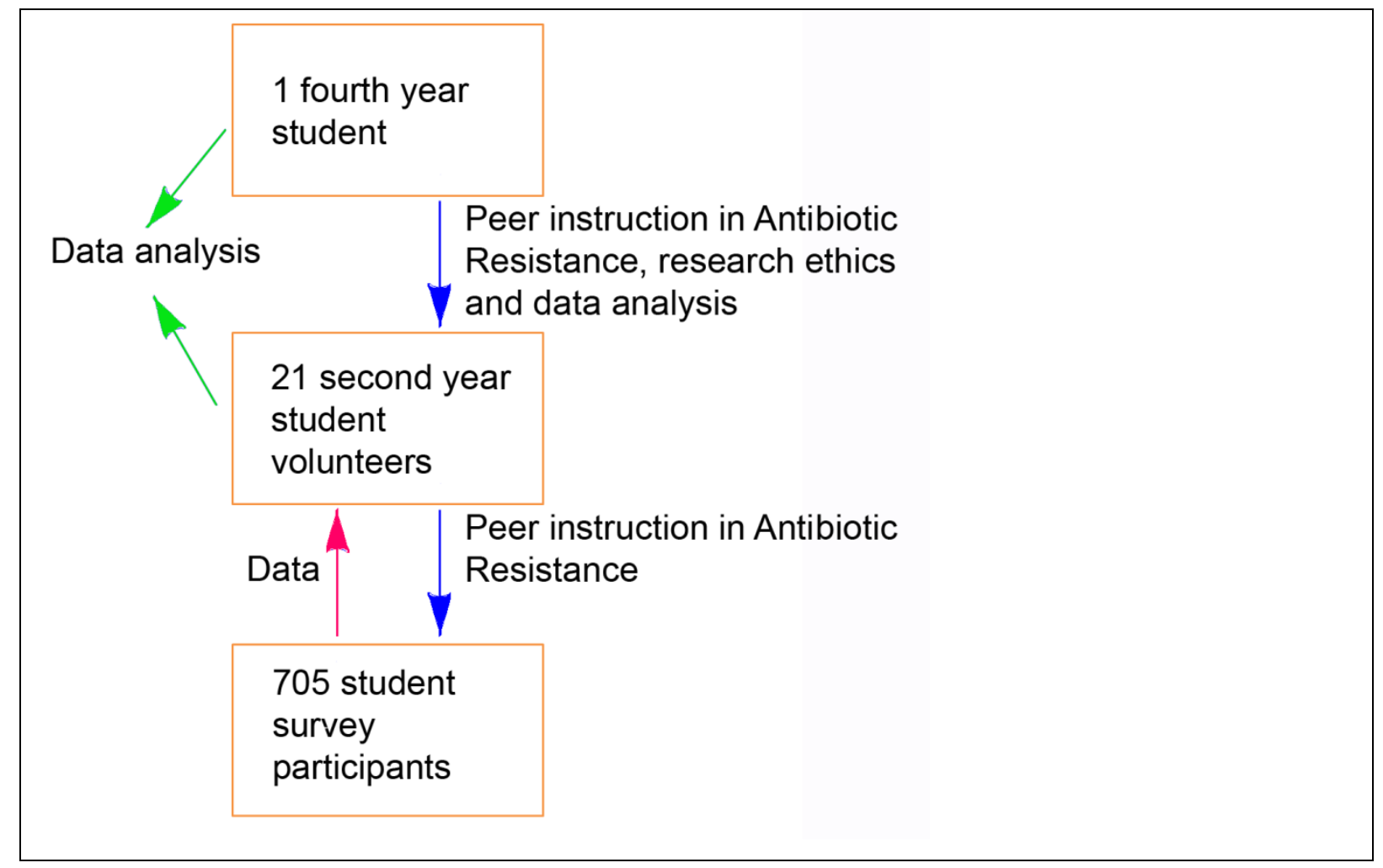

\section{Project design and implementation}

The first task for the final year student (SI) was to design, pilot and validate a questionnaire that would make up the survey. The focus of the survey was on practical ways in which the survey participants could help to limit antibiotic resistance. We were, however, aware that the participants would be university staff and students who would expect a clear rationale to underlie any request to reconsider their behaviour. The questionnaire was tested on 100 final year pharmacy students who gave constructive feedback resulting in a few minor changes (largely clarification of language). The final form of the questionnaire is presented in Appendix 1.

Ethical issues were explicitly addressed by the fourth year student. Although formal ethics committee approval is not normally required for the collection of non-sensitive data, without identifiers, when the issues are unlikely to upset or disturb participants, we deemed it essential that the fourth year student determined this for herself and explained 
the principles to the second year students. It was especially important for them to explain that participation was voluntary and participants could withdraw at any time.

Recruitment of second year students involved a short presentation by SI. Volunteers received an Antibiotic Guardian tee-shirt (Figure 2) to allow them to be clearly identified in a crowded building, and a small amount of credit (for volunteering) in the Manchester Leadership Programme (http://www.college.manchester.ac.uk/awards/manchesterleadershipawardm/p/).

Volunteers were required to sign an Antibiotic Guardianship pledge (http://antibioticguardian.com/).

Figure 2. Antibiotic Guardian tee-shirt (designed by Sadaf Ilias, modelled by a second year volunteer, lqra Zafar, photograph by Ed Swindells). Funding for teeshirts was though a grant from the University of Manchester's (2015) 'Learning through research' fund.

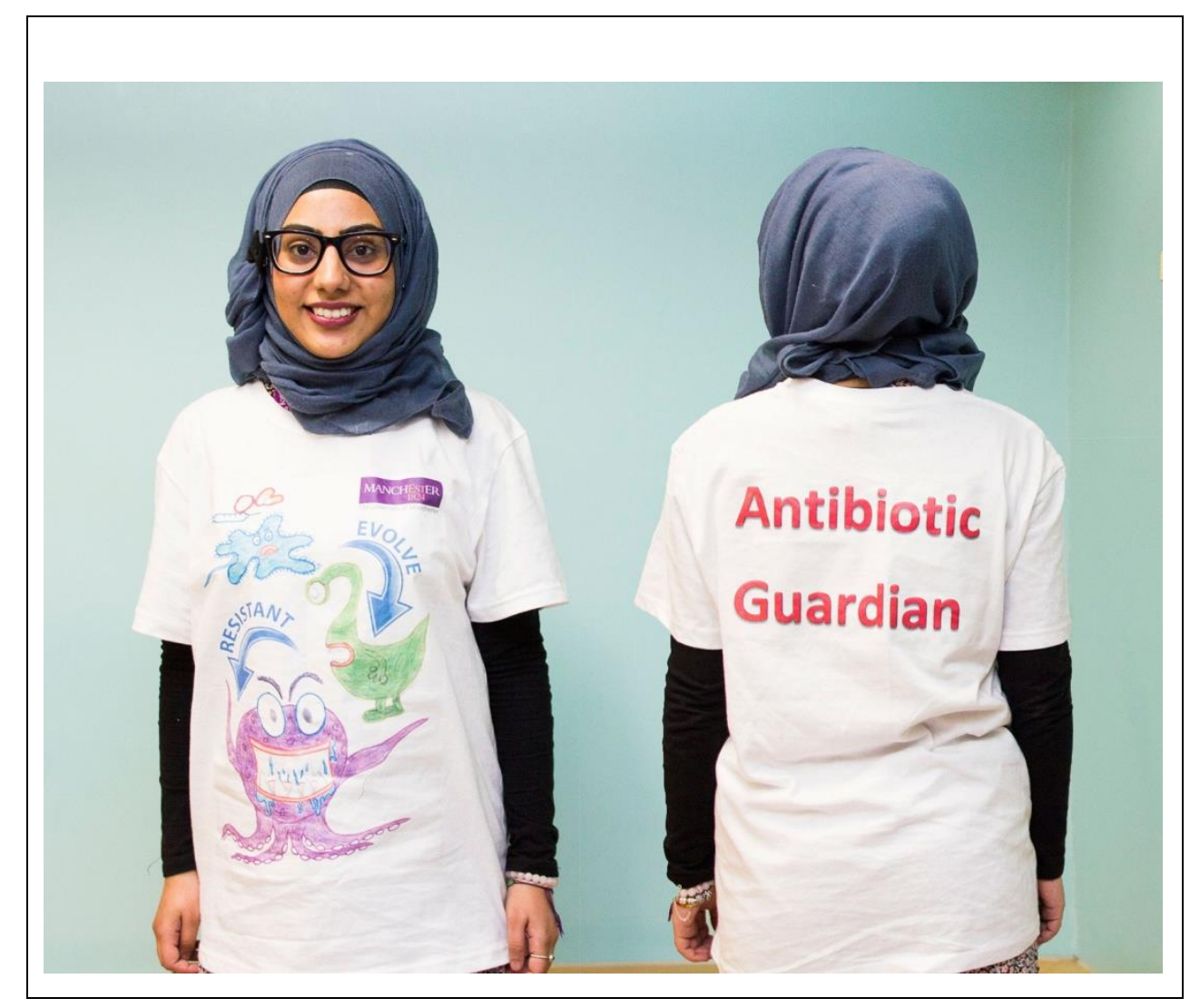

The fourth year student briefed the volunteers on both antibiotic resistance (reinforcing course material) and on research ethics, using role play exercises to ensure that they fully 
understood their role. Although the Antibiotic Resistance Survey can, in principle, be conducted using members of the public as participants, university premises were chosen for the first survey because participants were expected to be broadly sympathetic to the aims of the project. The building chosen for the survey houses students in Medicine, Pharmacy, other healthcare subjects and Life Sciences. These groups are expected to have a great deal of influence over Antibiotic Guardianship in their future careers. The survey was conducted over a period of one week. Each volunteer collected data for a total of about 5 hours. Nobody was excluded from taking part in the survey but responses from non-students were excluded from the data analysis.

Data suitable for analysis were collected on paper forms from 705 student participants, entered manually into Excel and then imported in SPSS version 20. About 40 additional questionnaires were collected from academic and support staff.

The results of the survey will be reported elsewhere. Key findings were: $81.5 \%$ of healthcare students $(n=411)$ and $73.3 \%$ of Life Sciences students $(n=251)$ understood that antibiotics can be used to treat some pneumonias but not colds, flu, and sore throats. $91.5 \%$ of healthcare students and $86.5 \%$ of Life Sciences students understood that premature discontinuation of treatment can contribute to antibiotic resistance. Life sciences students (87.7\%) were more likely than healthcare students $(81.6 \%)$ to understand that the use of antibiotics as growth promoters in farm animals is a cause of antibiotic resistance. Only $55.2 \%$ of healthcare students and $45.1 \%$ of Life Sciences students understood the importance of good hygiene in limiting antibiotic resistance and this finding was immediately communicated to academic staff so that it could be reinforced in classes.

The volunteers (16 out of 21) filled in a short feedback form using a Likert scale (strongly agree, agree, uncertain, disagree, strongly disagree) and descriptive statistics are given in Table 1. 
Table 1. Student volunteers' perceptions of conducting the Antibiotic Resistance Survey.

\begin{tabular}{|l|c|c|c|c|c|}
\hline & $\begin{array}{c}\text { Strongly } \\
\text { agree }\end{array}$ & Agree & Uncertain & Disagree & $\begin{array}{c}\text { Strongly } \\
\text { disagree }\end{array}$ \\
\hline $\begin{array}{l}\text { I was well informed about the } \\
\text { purpose of the research } \\
\text { project }\end{array}$ & 11 & 6 & 0 & 0 & 0 \\
\hline $\begin{array}{l}\text { I was aware of my role as a } \\
\text { volunteer }\end{array}$ & 13 & 4 & 0 & 0 & 0 \\
\hline $\begin{array}{l}\text { The instruction to conduct my } \\
\text { role was clear and concise }\end{array}$ & 11 & 6 & 0 & 0 & 0 \\
\hline $\begin{array}{l}\text { I have gained communication } \\
\text { skills and confidence by } \\
\text { surveying the students and } \\
\text { staff }\end{array}$ & 11 & 6 & 0 & 0 & 0 \\
\hline $\begin{array}{l}\text { I have enhanced my } \\
\text { knowledge regarding } \\
\text { antibiotic resistance }\end{array}$ & 12 & 5 & 5 & 0 & 0 \\
\hline $\begin{array}{l}\text { I have managed to raise } \\
\text { awareness about antibiotic } \\
\text { resistance amongst students } \\
\text { and staff on campus }\end{array}$ & 11 & 4 & 0 & 0 \\
\hline $\begin{array}{l}\text { I have gained analytical skills } \\
\text { from analysing the data } \\
\text { gathered }\end{array}$ & & 5 & 0 & 0 \\
\hline
\end{tabular}

There were no unforeseen difficulties in conducting the survey and the students' efforts were well-received by participants.

\section{Discussion}

A significant body of literature about peer-to-peer learning in higher education has been reviewed by Keenan (2014). The most prevalent models are Peer Assisted Learning (PAL) 
and Peer Assisted Study Sessions (PASS), which are deeply embedded and validated in many university courses. Leaders of these sessions are believed to be the main beneficiaries (Dawson et al., 2014; Becker and Fostier, 2015), gaining employability skills, and Hilsdon (2013) has commented on the social focus of PAL. Nevertheless, the headline objective of most peer-to-peer learning is to aid learning for success in assessments. Typically, but not exclusively, leaders are second year students and learners are first year students.

The headline objective of our model is different. We sought to deliver an important healthcare message to a wider public (in this pilot most of the wider public were students) with the ultimate purpose of saving lives. We used a peer-to-peer cascade to embed an understanding of antibiotic resistance in second year pharmacy students and then in a body of over 700 students. We believe that the peer-to-peer learning cascade is novel, and an important feature is that the learning by the final (large) group is quite simple and capable of being expressed in a few minutes. Another important point is that the second year students did not expect directly to improve their examination performance as a result of this activity. They were recruited as volunteers, rather than as learners.

Nevertheless, the second year student volunteers believed that this approach had improved their understanding of antibiotic resistance and they valued the opportunity to practise communication of healthcare issues, believing that their communication skills had improved. We cannot yet determine whether the second stage of the cascade (student volunteers talking to other students) was successful in raising awareness of antibiotic resistance among the larger group.

Both the second year and the fourth year students were given an opportunity to learn through research. Second year students were fully briefed on the practical and ethical considerations of carrying out a large scale research project using human subjects. They found the data analysis relatively difficult but were able to develop their understanding of this aspect of the project.

The exercise was therefore very largely successful in achieving its aims. We are currently repeating it with some modifications: replacing paper forms with i-pad based 'e-forms' which send data to a central computer; recruiting participants from a wider range of 
student disciplines; and seeking to understand which aspects of the activity were most valued by the second year students.

The peer-to-peer cascade could be used to deliver many important healthcare messages, but might be equally powerful in delivering short messages in the arts and humanities. One topical example might be an introduction to the Easter 1916 Uprising delivered by History students.

\section{Conclusion}

The Antibiotic Resistance Survey is an example of a peer-to-peer learning cascade, in which a final year student trained 21 second year students to deliver a healthcare message to over 700 university staff and students. The second year students learned through carrying out research and through communicating an important healthcare message to other people. The activity may also be expected to yield benefit in terms of raising public awareness of antibiotic resistance. The peer-to-peer learning cascade differs from established models such as PASS and PAL in a number of respects, most importantly that the participants were not expecting to improve assessment scores as a result of the activity. 21 second year students (in this case) had the opportunity to practise important skills, but the final learning was a simple healthcare message.

\section{Acknowledgements}

We are grateful for a grant from the University of Manchester's 'Learning through research' fund; to the 21 second year student volunteers; and to over 700 students and staff who participated in the Antibiotic Resistance Survey.

\section{References}

Barber, J. (2015) Critical analysis and communication: an alternative research project for Pharmacy students. Higher Education Academy: Innovative Pedagogies Project. Available at: https://www.heacademy.ac.uk/critical-analysis-and-communicationalternative-research-project-pharmacy-students (Accessed: 1 April 2016). 
Becker, R. and Fostier, M. (2015) Evaluating non-compulsory educational interventions the case of peer assisted study groups. The University of Manchester Economics Discussion Paper Series EDP-1509. Available at http://hummedia.manchester.ac.uk/schools/soss/economics/discussionpapers/EDP_ 1509.pdf (Accessed 29 April 2016).

Cameron, D. (2014) Press release: Prime Minister warns of global threat of antibiotic resistance. Prime Minister's Office, 2 July. Available at https://www.gov.uk/government/news/prime-minister-warns-of-global-threat-ofantibiotic-resistance (Accessed: 16 November 2015).

Crouch, C. and Mazur, E. (2001) 'Peer Instruction: ten years of experience and results', Am. J. Phys, 69(9), pp. 970-977.

Dawson, P., van der Meer, J., Skalicky, J. and Cowley, K. (2014) 'On the effectiveness of supplemental instruction: a systematic review of supplemental instruction and PeerAssisted Study Sessions literature between 2001 and 2010', Review of Educational Research, 84(4), pp. 609-639.

Demonacos, C., Aarons, L. and Barber J. (2014) 'Critical analysis and communication: an alternative to the research project', HEA Health and Social Care Education 2014, pp. 1-5.

European Centre for Disease Control, European Medicines Agency (2009) The bacterial challenge: time to react. $A$ call to narrow the gap between multi-drug resistant bacteria in the EU and the development of new antibacterial agents 2009. Stockholm: European Centre for Disease Prevention and Control.

Gandra, S., Barter, D.M. and Laxminarayan, R. (2014) 'Economic burden of antibiotic resistance: how much do we really know?', Clin. Microbiol. Infect, 20(10), pp. 973980.

General Pharmaceutical Council (GPhC) (2011) Future pharmacists. Standards for the initial education and training of pharmacists. (pp 37 and 33). Available at: http://www.pharmacyregulation.org/sites/default/files/Standards\%20for\%20the\%20i 
nitial\%20education\%20and\%20training\%20of\%20pharmacists.pdf (Accessed: 29 March 2016).

Godlee, F., Smith, J. and Marcovitch, H. (2011) 'Wakefield's article linking MMR vaccine and autism was fraudulent', BMJ, 342(5 Jan), c7452.

Hilsdon, J. (2013) 'Peer learning for change in higher education', Innovations in Education and Teaching International, 51(3), pp. 244-54 [Online]. Available at: http://dx.doi.org/10.1080/14703297.2013.796709 (Accessed: 1 April 2016).

Keenan, C. (2014) Mapping student-led peer learning in the UK. York: Higher Education Academy. Available at: https://www.heacademy.ac.uk/sites/default/files/resources/peer led learning keen an nov 14-final.pdf (Accessed: 29 March 2016).

Kollef, M.H., Sherman, G., Ward, S. and Fraser, V. (1999) 'Inadequate antimicrobial treatment of infections: a risk factor for hospital mortality among critically ill patients', Chest J., 115(2), pp. 462-474.

Pinder, R., Sallis, A., Berry, D. and Chadborn, T. (2015) Behaviour change and antibiotic prescribing in healthcare settings: literature review and behavioural analysis. London: Public Health England. Available at: https://www.gov.uk/government/uploads/system/uploads/attachment data/file/4050 31/Behaviour Change for Antibiotic Prescribing - FINAL.pdf (Accessed: 16 November 2015).

University of Manchester (2015) Learning through research. Available at: http://www.manchester.ac.uk/study/undergraduate/teaching-learning/methodsmaterials/research/ (Accessed: 16 November 2015).

\section{Author details}

Sadaf Ilias graduated from the Manchester Pharmacy School in 2015 and is currently working towards registration as a Member of the Royal Pharmaceutical Society. Her 
ambition is to practise in primary healthcare alongside GPs to provide optimal patient outcome. She also aims to become an independent prescriber.

Jill Barber completed her B.A. and Ph.D. in Chemistry at the University of Cambridge but is now a Reader in Pharmacy at the University of Manchester. She maintains an active research group in Pharmacoproteomics as well as pursuing innovations in teaching, especially e-learning and e-assessment. She was awarded a National Teaching Fellowship by the Higher Education Academy in 2014. 


\section{Appendix 1. Questionnaire survey attached with patient information leaflet}

Antibiotic Resistance Survey

\section{MANCHESTER 1824}

The University of Manchester

I am a fourth year pharmacy student and I would like you to participate in my research survey which is approved by the University of Manchester. The purpose of this survey is to assess your knowledge regarding antibiotic resistance. By taking part in this research, it will benefit you by raising your awareness on antibiotic resistance and benefit the university in future teaching and development.

Your participation in this research is entirely voluntary and you are free to withdraw whilst filling out the survey without giving reason. You can provide a unique identifier number to enable you to withdraw your data within 48 hours after handing the survey. The information you provide is anonymous and if the data is shared or published your anonymity will be preserved.

You can email the researcher for any questions or decide to withdraw your survey data sadaf.ilias@student.manchester.ac.uk.

Please tick the box to confirm that you have understood the purpose and provide consent to undertake this survey

1.) Please state your occupation or degree course that you are studying

2.) Which of the condition listed below do you think should be primarily treated with an antibiotic?

(Please tick ONE option)

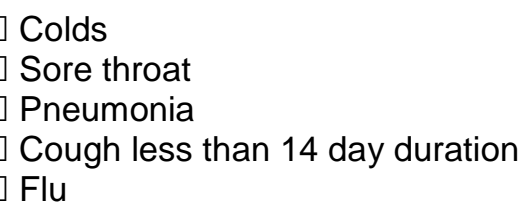

3.) Can you name an antibiotic?

4.) Tick any of following that you think antibiotics are effective against:
$\square$ Fungi
$\square$ Bacteria
$\square$ Worm
$\square$ Virus

Bovine Spongiform Encephalopathy

5.) Are you aware of the term antibiotic resistance?
Yes
$\square$ No

\section{If yes, then please continue filling out the survey}

6.) How have you heard of the term antibiotic resistance?
$\square$ News
$\square$ Newspaper
$\square$ Lecture
Personal experience 
$\square$ Other please state

7.) Which of the following statements do you think is the correct definition of antibiotic resistance? (Please tick ONE option)

$\square$ Antibiotic kills the microorganisms and treats the infection

$\square$ Microorganisms can withstand the action of the antibiotics and is able to multiply and spread causing severe infections

$\square$ Virus can resist the action of antibiotics causing severe infection

8.) Antibiotic resistance is a major concern worldwide due to adverse impact on health and economy? (Please tick ONE option)
True
False
Don't know

9.) Resistant bacteria are bacteria that is not controlled or killed by an antibiotic. An example of such bacteria is $C$. difficile.

\section{Can you provide another example of antibiotic resistant bacteria?}

10.)Which of the conditions below are becoming difficult to treat due to antibiotic resistance?

$\square$ TB

$\square$ Urinary tract infection

$\square$ Gonorrhoea

$\square$ Meningitis

$\square$ All of the above

11.) Which of the practices below do you think could contribute to antibiotic resistance:
Individual stop taking antibiotic once they feel better
$\square$ Yes $\square$ No
Overuse of antibiotics in farming animals
$\square$ Yes $\square$ No
Prescribing narrow spectrum antibiotic for known causative agent
Yes $\square$ No
Inadequate hygiene practices
$\square$ Yes $\square$ No
Sharing antibiotics with family and friends
$\square$ Yes $\square$ No

12.) Provide THREE examples how you can play a role in minimising the risk of antibiotic resistance development?

1.)

2.)

3.)

Thank you for participating! 